\title{
A means to an end
}

\section{Media strategies and films commissioned by Svenska Europahjälpen in the late 1940s}

\author{
Åsa Bergström
}

To help fund the Swedish relief programme, donate one day's wages to Swedish European Aid postal account 900 700. ${ }^{1}$
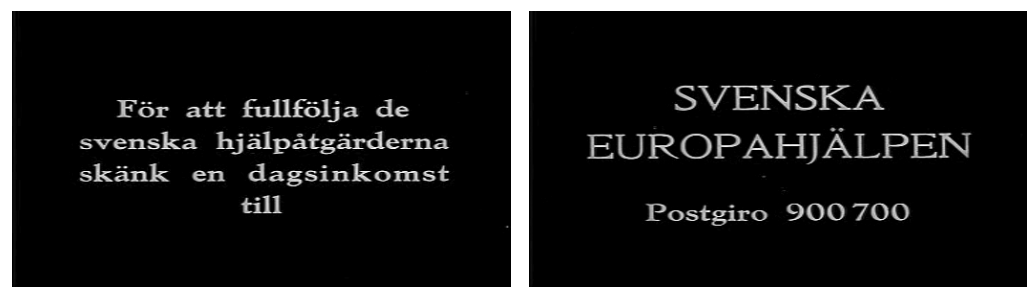

Screenshots from Barnen är utan skuld-Svenska hjälpverksamheten $i$ Wien ('The children are blameless-The Swedish relief programme in Vienna', 1946, dir. Eduard von Borsody). Courtesy of Sveriges Television AB.

In Sweden, the humanitarian organizations Röda Korset (Swedish Red Cross, RK) and Rädda Barnen (Swedish Save the Children, RB) reveal an apparent awareness of the impact of film. Throughout the Second World War, RK appeared in several films, primarily in relation to reports of refugees arriving in Sweden and the 1945 rescue transport with the White Buses. These films presented some of the consequences of the Second World War and the Holocaust, promoting neutral Sweden as an active helping hand. During the immediate post-war period, the short-lived organization Svenska Europahjälpen (Swedish European Aid, SE) suddenly commissioned a number of films. These post-war representations are best described as educational and promotional films, supplemented by explicit spoken or written 
exhortations to donate money, exemplified by the quotation with which I opened this chapter.

The aim of this survey is to investigate the SE's media strategy and its consequences. The survey is performed in three steps, with an overview of the theoretical approaches to testimonies of war and representations of trauma followed by a mapping of the SE and its media strategies. Finally, the films that the SE commissioned and promoted are analysed and related to a discussion of representations of testimony and trauma.

\section{Representations of trauma}

Given that representations of traumatic events are dependent on the when, where, and how, one way to think about them is to use the two phases identified by Joshua Hirsch apropos representations of the Holocaust.

When photographic evidence of genocide first appears, it may need relatively little narrative support in order to cause vicarious trauma. It would be enough for the image to be presented by a reputable source (newspaper, magazine, newsreel), to be identified in historical context ('this is a liberated concentration camp'), and to be authenticated ('this is an actual photo taken by Allied photographers').... In the second phase, when relatively unsupported images are no longer effective, the film must, in a sense, work harder. It must overcome defensive numbing. Documentary images must be submitted to a narrative form whose purpose is, if not to literally traumatize the spectator, then to invoke a posttraumatic historical consciousness-a kind of textual compromise between the senselessness of the initial traumatic encounter and the sense-making apparatus of a fully integrated historical narrative, similar to LaCapra's notion of 'muted trauma.'

Hirsch's distinction, like LaCapra's notion of 'muted trauma', is a useful clarification, although I find it limiting to define representations of the Holocaust as either 'traumatic' or 'post-traumatic', and of course national differences in approach to specific traumas have to be contextualized and set in perspective. Yet despite these minor objections, 
Hirsch's approach and LaCapra's notion of 'muted trauma' are applicable in a Swedish context, where the films representing Swedish relief work in the aftermath of the Second World War coincided with the transition from the first to the second phase of Holocaust representations.

Like Hirsch, Cecile Felicia Stokholm Banke distinguishes between the phases of Holocaust representation, yet on different grounds. ${ }^{3}$ Stokholm Banke argues that post-war modes of visualizing the Holocaust 'can be divided into three phases, which were, and continue to be, tied to a political context. ${ }^{4}$ Commencing immediately after the war, the first phase largely comprised black-and-white photographs of the camps. Her examples from the second phase are drawn from the 1950 s to the 1990s, and different artists' interpretations of documented images of the genocide. These artists are said to have been in the camps themselves, or they 'had been on the spot when the American soldiers entered Nordhausen and Buchenwald.5 It was in this second phase that 'the ideological battle about how to understand the Holocaust began.' In the third, ongoing phase, the Holocaust 'is remembered, genocide is acknowledged, the victims receive compensation. ... In addition to its contribution to the culture of memory, the Holocaust has inspired a vast number of artistic and literary works.7 Stokholm Banke also spies a potential forth phase in the making, when the normative impact of the Holocaust 'has moved from something directed inwards to European societies to something directed outwards-a universal symbol of evil that is relevant not only for Europe but for the entire world.'

Notwithstanding the political impact, I find it counterproductive to rely solely on an omniscient perspective when analysing historical representations such as exhibitions, novels, documentaries, or feature films, if only because it risks excluding the parameters of media specificity, aesthetics, and contextualization. To elaborate on Hirsch's and Stokholm Banke's distinctions, I would suggest using a 'phase zero'-which in its initial state could be considered 'pretraumatic'during which traumatic events such as the Holocaust are difficult, if not impossible, to represent. This owes something to LaCapra's notion of 'muted trauma', introduced in a discussion of the nine-hour French Holocaust documentary Shoah (1985, dir. Claude Lanzmann): 'In the case of Shoah, the issue of length is nonetheless more problematic. On the one hand, one might argue that the very subject of the film ... is so 
vast and important that any length is small and inadequate-indeed that the very length, seeming repetitiveness, and empty stretches or silences of the film are necessary to transmit to the viewer a muted trauma required for empathetic "understanding"'. Then again, I do not find the sequence of phases either entirely linear or completely consistent. To grasp the full consequences of traumatic events, different kinds of images and narratives are crucial. Due to the fact that such representations change over time, I find that what I describe as phase zero appears, declines, and reappears over the years, each time in a different form. It is therefore important to consider and contextualize these transformations and their representational consequences. Film from liberated concentration camps was being shown in cinemas in Sweden as early as April 1945, yet the word 'Holocaust' ('Förintelsen' in Swedish) was not in use in the immediate post-war period. Raul Hilberg emphasizes that: 'In the beginning there was no Holocaust. When it took place in the middle of the twentieth century, its nature was not fully grasped. ${ }^{\prime 10}$

By stressing the problems he ran into with his book The Destruction of the European Jews, finally released in conjunction with the trial of Adolf Eichmann in 1961, Hilberg characterizes the immediate postwar period by its obvious lack of interest in the consequences of the Nazi regime. ${ }^{11}$ Dori Laub says much the same thing when coining his theory of bearing witness, arguing 'that what precisely made a Holocaust out of the event is the unique way in which, during its historical occurrence, the event produced no witnesses. ${ }^{\prime 2}$ Given the effectiveness of the Nazi machinery and the murder on an industrial scale, this is of course a relevant observation. Nevertheless, I would argue that it is crucial to widen Laub's theoretical approach to Holocaust testimony.

First, the impact of surviving witnesses who have given testimony in the trials of Nazis, as well as the vast variety of Holocaust testimony communicated through witness literature, film, television, theatre, exhibitions, and lectures by survivors, must not be ignored. Second, and just as relevant, there are many different ways to bear witness. The earliest testimony to the full horrors of the Nazi regime was silent, after all. Stills and film of dead bodies and silent survivors communicate just as clearly. A more distanced, yet equally emotional, way of communicating such silent testimony are the images of piles of bodily 
remains and personal belongings-hair, false teeth, spectacles, prostheses, shoes, clothing, suitcases et cetera. These human remains and belongings bear silent witness to the lives of the anonymous people they once belonged to. Silent testimony is often interpreted in written texts or voice-over, and accordingly the dialogical relation between embodiment and voice is essential in this context.

Thinking about human rights and memory, Daniel Levy and Natan Sznaider argue:

By rooted cosmopolitanism we mean universal values that descend from the level of pure abstract philosophy and engage people emotionally in their everyday lives. It is by becoming symbols of people's personal identities that cosmopolitan philosophy turns into a political force. By embodying philosophy in rituals, such identities are created, reinforced, and integrated into communities. ... War crimes trials exemplify such rituals, given the extensive media and scholarly attention they receive. This emotive dimension is also a crucial element for some of the shared assumptions that guided the cosmopolitan reactions to the catastrophes of World War II. The Holocaust in particular posed a challenge to the universal Enlightenment premises of reason and rationality. ${ }^{13}$

Much like the war crimes trials, relief work in the immediate post-war period can be considered an emotive and ritual response to the catastrophes of war. ${ }^{14}$ In turn, the films depicting relief not only collectivize reactions to the horrors of the war, they also confirm that the work they show has actually been done. Moreover, the films performatively encourage individual viewers to partake by donating money.

There has been little work done on the films included in this survey, and research on the SE is just as absent. There is some literature on the RK and the RB, although when it comes to the RK, whose rescue action with the White Buses just preceded the formation of the SE, it should be noted that the priorities which made it possible to rescue certain groups of concentration camp prisoners, and the potential impact a certain Swede, Count Folke Bernadotte, had on these actions, have come in for criticism and scrutiny. ${ }^{15}$ Regarding the RB, Ann Nehlin argues that: 
Rädda Barnen seems to have been somewhat reluctant to support Jewish children, but in the early fifties this changed and relief work in Israel was carried out in conjunction with Swedish authorities. Here as well, as part of the activities, it was important to generate goodwill for Sweden. Perhaps the most visible sign of this was the establishment of the Swedish village Kfar Achim. ${ }^{16}$

Suitably rephrased, Nehlin's observation can constructively be used as a research question in the present survey. Is it possible to identify a gradually altered approach towards children, adolescents, and adults of different nationalities, classes, genders, and perhaps also religions in the films representing the relief work promoted by the SE in the late 1940s?

\section{Three Swedish humanitarian organizations}

As a response to what the Swiss banker Henry Dunant witnessed on the battlefield at Soferino in Italy 1859 , the Red Cross (RC) was founded in 1863 . With an explicit aim of assisting people in need, regardless of nationality, class, and gender, the movement presently incorporates the Geneva-based International Committee of the Red Cross (ICRC) and the International Federation of Red Cross and Red Crescent Societies (IFRC), as well as national societies in 186 countries. ${ }^{17}$ In Sweden, Röda Korset (RK) was founded on 24 May 1865, its first years being devoted to preparations for humanitarian aid in the event of war, while later in the interwar years it also worked to improve conditions for Sweden's poor. ${ }^{18}$ Subsequent changed priorities, which made it possible for the RK to countenance saving certain groups in its rescue actions with the White Buses in 1945, plus Bernadotte's impact at the time, are reflected in its official website, which includes information on the debate and online access to certain documents. ${ }^{19}$

Initiated by Eglantyne Jebb, the organization Save the Children Fund (SCF) was officially founded in the UK on 19 May 1919, with the self-appointed task of improving children's rights. ${ }^{20} \mathrm{~A}$ mere six months later Rädda Barnen (RB) was set up in Sweden and in 1920 the Swedish organization joined the International Save the Children Union (ISCU). Over the years, the RB has stressed its political and religious independence, its slogan still prominent on its website. ${ }^{21}$ More 
importantly here, in 1946 the RB's influence increased exponentially in the international arena, and it is not too farfetched to consider this a key factor in its initiation of an entirely new cooperative venture with the RK that same year. ${ }^{22}$

On 9 February 1946, the RB convened a meeting to 'form a committee with the purpose of centralizing the Swedish relief work in Europe. ${ }^{23}$ This led to the formation of Svenska Europahjälpen (SE), which would exist until April 1951. The minutes of the next joint meeting, 15 February 1946, includes a list of the members of the Steering Committee, with both the RK and the RB represented. ${ }^{24}$ One of the points in the minutes is an all-important resolution:

Every single day we receive new reminders of the needs of the war-torn countries of Europe. ... Crowds of orphans, nameless and homeless children, know nothing but hunger, disease and suffering. Thanks to the great contributions made by Swedish citizens, help has already reached certain countries. The needs are limitless and the circumstances more serious than ever. What could be more natural than that we, the Swedes, who fortunately were spared the devastating war, and gradually are enjoying improved living conditions, join forces to provide assistance on an even greater scale. Contributions can be made to SE's postal account-900 700 . If contributions are intended for a specific country, this should be indicated on the payment slip. Every donation goes to activities carried out by the organization. -Stockholm, 15 February 1946. ${ }^{25}$

The resolution was signed by approximately forty different organizations, some of the signatories, such as Folke Bernadotte, having been involved with relief work in the past. ${ }^{26}$ Despite the fact that the SE comprised a large range of organizations, its minutes reveal that the $\mathrm{RK}$ and the $\mathrm{RB}$ representatives dominated the new organization. The reason why the SE was so short-lived is not clear, yet the decision to disband it was unanimous, as was the choice to split its remaining funds equally between the RK and the $\mathrm{RB} \cdot{ }^{27}$ 


\section{SE's media strategies}

The minutes show that the SE Steering Committee was alert to the impact of media strategies and different forms of propaganda. The minutes of its second meeting on 15 February 1946 append a list of possible propaganda outlets-daily newspapers, magazines, radio, newsreels, films, and poster campaigns are all there. ${ }^{28}$ An early report mentions that 'a speech by the Prime Minister will be simultaneously screened in 600 Swedish cinemas between 29 April and 7 May' and that 'the estimated cost of producing the film copies is SEK 7,000.'29 Unfortunately, none of the minutes indicate the title of this film, which makes it difficult to identify in the archives, and the same is true of the cinema advertisement. Even so, it is clear that the Steering Committee's initial conviction that film was an effective propaganda tool was only strengthened in 1946 and 1947. In the minutes for 4 September 1947, their choices for how to mark the Ruby Jubilee-the celebration of King Gustaf V's forty years on the Swedish thronehad boiled down to 'The Royal Pin 1947' (of small interest here) and 'The Royal Film':

The second project concerns the production and distribution of a 'Royal Film', depicting important events and developments in Sweden in King Gustaf V's reign, the proceeds to go to European Relief. Investigations into financially profitable ways of producing and distributing the film have been initiated. In connection with the screenings of the 'Royal Film', a suitable short film illustrating the relief work performed in Europe by either RB or RK will be shown. ${ }^{30}$

The minutes for 28 April 1947 clarify that the film, now with the distribution title 40 år med Kungen ('40 years with the King', 1947, dir. Gösta Werner), had been swiftly produced by Kinocentralen and was about to be distributed by AB Europafilm. It was stressed that production costs 'have been covered by individual donors. ${ }^{31}$ A note from the SE National Conference in 1949 underlines that the film 'through the cinemas' kind offices has been shown countless times all over the country, which has generated about SEK 266,00o for the SE.'32 This indicated that, needless to say, their expectations of a high box office 
and impact had been met. The takings continued to grow, and at the very last meeting, which marked the endpoint of the organization on 21 December 1951, an updated figure of SEK 275,000 is mentioned. ${ }^{33}$ Over the years, in fact, the minutes contained several reports of the income it generated, yet even so there is very little information about the distribution and screenings of the film.

Today, 40 år med Kungen, which opened in Swedish cinemas in December 1947, is listed in the main film databases-Svensk Filmdatabas (Swedish Film Database, SFDB) and Svensk mediedatabas (Swedish Media Database, SMDB) — and is still easily accessible. ${ }^{34}$ The film consists of a mix of contemporary and archive footage, and covers the period from King Gustaf V's coronation in 1907 to his Ruby Jubilee in 1947. Consequently, much of the historical reportage had been filmed before the advent of sound, and apart from the last sequence, where King Gustaf V read a speech addressed to 'every Swede' from a script, Sven Jerring provides the voice-over. In Sweden, Jerring was famous as a radio announcer and for leading his long-running radio show for children, Barnens brevlåda ('Children's Letterbox', 1925-1972), which earned him the nickname 'Farbror Sven' ('Uncle Sven'). Jerring's instantly recognizable voice would have been the ideal choice for a film calling for donations aimed at Europe's children.

The minutes show that 40 år med Kungen was commissioned by the SE, and in the opening credits the SE's name appears over the royal emblem. The film is distinctly royalist in tone, and emphazises Sweden's steadily improving living conditions over the forty years depicted. Almost nothing is said of the Second World War or the post-war situation-whether in Sweden or elsewhere-and the only
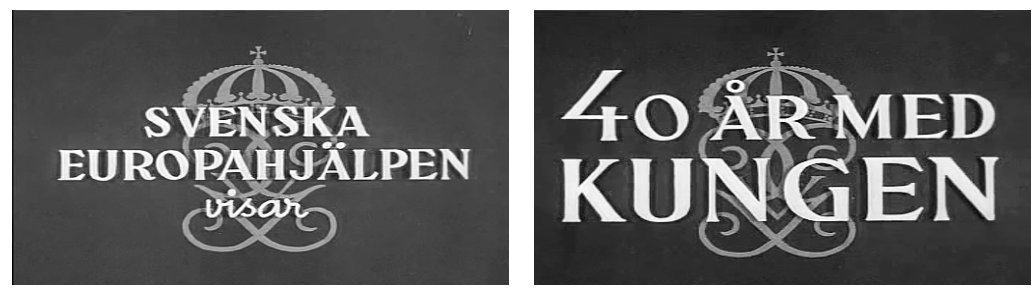

Screenshots from 40 år med Kungen ('40 years with the King', 1947, dir. Gösta Werner). Courtesy of Sveriges Television AB. 
footage of refugees dates from the First World War. To sum up, the benefits that 40 år med Kungen brought the SE say something about the impact and popularity of King Gustaf V, but the film says nothing at all about Swedish relief work in 1947.

When it comes to other SE-related films, there is again a distinct lack of information about their distribution and screening. However, we can get a general sense of what was expected and potential target groups from the SE minutes:

In order to attract young people's interest, the SE can on request lend the following films for a small charge to cover postage (order from Filmo, Saltmästargatan 8 , Stockholm):

(a) Barnskor (13 min)

(b) Barnen är utan skuld (c.15 min)

(c) Hemlösa (20-25 min)

(d) Med Rädda Barnen i Rumänien (10 min)

(e) Hade Ni glömt (c.25 min)

(f) För pest och hungersnöd (c.20 min $)^{35}$

I have tracked down the first four films, but the fate of the last two is presently unclear. Because of the vague information about distribution, it is unfortunately difficult to tell where and when the films were screened, a problem compounded by the SE minutes, in which the films seem to be randomly listed. In an attempt to make sense of what information there is, I will discuss the films according to their estimated year of production. The SFDB lists only two of the films-Barnskor and Hemlösa-while the SMDB has all four. ${ }^{36}$ The duration of the known copies is not entirely consistent with the estimated lengths given in the list above, and it is thus tricky to tell if the digitalized versions are the same as the versions distributed in the late 1940 s. $^{37}$

\section{Children are blameless}

The first film the SE commissioned appears to have been Barnen är utan skuld-Svenska hjälpverksamheten $i$ Wien ('The children are blameless-The Swedish relief programme in Vienna', 1946, dir. Eduard von Borsody). ${ }^{38}$ The SFDB has no information on the film, 
while there is a short summary in the SMDB. ${ }^{39}$ A Swedish-Austrian co-production, it combines documentary footage of Viennese exteriors with dramatized scenes in German by the Austrian director and actor Willi Forst. ${ }^{40}$ There are no Swedish subtitles, a fact for which there are two tentative explanations: the version provided by SMDB might not be entirely consistent with the version distributed in Sweden in the late 1940 and early 1950s; and German was long the first foreign language studied in Sweden, and it was still the case that many Swedes spoke reasonable German in the post-war period. ${ }^{41}$

After the opening credits, which end with a pointedly symbolic turning of pages, an intertitle explains the funding of the Swedish relief programme: 'Subsidized by the Swedish government and organized by RB, Swedish relief in Austria commenced on 4 February 1946. Covering children from three to six years of age, it has reached 64,000 children, 54,000 of them in Vienna.' This is followed by another intertitle that introduces Willi Forst, 'the famous director and actor, here presenting the sad state of Vienna and the welcome contributions from Sweden.'

The establishing shot has Forst entering through a stage curtain and approaching the camera, where he welcomes the viewers with a bow. $\mathrm{He}$ then delivers a prologue straight to camera, occasionally lowering his eyes to check the script. The scene then shifts to the city of Vienna, with Forst providing the voice-over, accompanied by the Austrian composer Franz Schubert's Eighth Symphony. The exterior sequences resemble the 1920 s films of modern city life-often described as city symphonies-yet the war-torn buildings of 1946 tell an entirely different story, distanced, emotive, about the passage of civilization and modernity. ${ }^{42}$

Exterior footage of children and adults collecting debris serves as a narrative bridge to a short dramatized sequence. In this brief family drama, Forst modulates his voice to portray different characters. A small girl is left alone at home while her mother and older siblings are out collecting firewood. When they return to their starkly empty working-class apartment one of the brothers, desperately hungry, asks for bread, but it is revealed that his younger sister has eaten it all, leaving only a few crumbs on the floor in the midst of her toys. Sheltering in their mother's arms, the small girl is confronted by the family, and her sad face is shown in medium close-up. Still comforting her youngest daughter, the mother knocks on the door of the 
neighbouring apartment, pleading for bread. The woman next door has none, but she solves the problem by telling the desperate mother about the help to be had from the 'Schwedischen Hilfsaktion', the Swedish relief programme.

As Forst describes the help on offer, the film cuts to a poster by 'Schwedischen Hilfsaktion Rädda Barnen' on a wall above a queue of women and children. A longer indoor sequence follows of grownups in uniform and children warming their hands by a fireplace and eating 'Die Schwedische', a Swedish soup of 'macaroni, vegetables, meat, and oatmeal with raisins'. Finally, 'Schwester Dagmar' speaks for the children in first person, saying 'Now I feel much better, and I am so fond of my Swedish soup, that no one, no one in the whole wide world can take it away from me.'

From the direct effect of the Swedish relief programme, the film moves on to the way the humanitarian work in Vienna is structured. Deliveries and food preparation are shown, and in voice-over Forst describes the immense work done by the RB. The film keeps showing the Swedish flag and the emblem of the RB on trucks and jackets, stressing the same point as Forst's voice-over-in 1946, the RB aimed to reach every Viennese child in need, as long as they were aged between three and six.

In the last sequence, Forst is back where he began, in front of the curtain, to deliver an epilogue in which he speaks for the whole of Austria, expressing the country's 'gratitude towards their Swedish friends and the RB'. He concludes his monologue in Swedish, with a noticeable German accent, and, as the screen fades to black, Forst is seen thanking the viewers by bowing again. The film ends with a final intertitle, quoted at the start of the present chapter, that explicitly encourages viewers to support SE: 'To help fund the Swedish relief programme, donate one day's wages to Swedish European Aid, postal account 900 700'.

With Forst's prologue, epilogue, and two bows the film resembles a theatrical performance in which RB plays the part of the good-hearted hero. Dramatic theory is generally concerned with if - and if so, how-a drama engages and affects its audience. Whenever a drama includes a hero, viewers tend to identify themselves with that specific character. Consequently, it would seem Barnen är utan skuld was consciously structured to engage its audience: the assumption seems to have been 
that, by identifying with the benevolent hero, they would be affected to such an extent that they too would join in the SE's relief programme by donating money.

\section{Children's shoes}

Like Barnen är utan skuld, the film Barnskor ('Children's shoes', 1947, dir. Eduard von Borsody) is a Swedish-Austrian co-production produced by Willi Forst-Film, and with a dialogue in German. The difference is that Barnskor has some Swedish subtitles. There are summaries of the film provided by both the SFDB and the SMDB. ${ }^{43}$

The title is also the pervading theme of the film, introduced by an establishing close-up shot of two feet, wearing worn-out shoes, stumbling through deep snow. In the next shot a group of grown-ups and children are struggling up a snowy slope. Suddenly one of the women collapses. Two of the men carry her to a seemingly derelict house, and as they lay her down on a bed she cries out 'I can't take it any longer-please take my children with you'. The three youngest immediately follow the two men out of the door, while the eldest stays behind. In medium close-up, the mother makes him promise to take care of his siblings. The brief exchange also reveals that his name is Peter. Just as he catches up with the others, his three siblings leave the group and run back to their mother. Peter goes after them, and when they enter the house they find their mother dead. The sequence that reveals the dead mother begins with a shot of her feet in ragged shoes.

This sequence is then revealed to be a flashback, telling the story of how Peter became an orphan. Flashbacks in film can be utterly subjective, internal, and traumatic. This is not the case here, however. The information the viewer is first given in the flashback is repeated by the real protagonist of the film, the RB, in the persona of the staff of one of its orphanages. Peter is given a voice, but he, his story, and his testimony are all objectified.

The scene moves first to an exterior shot of an RB orphanage, 'Kinderheim Rädda Barnen', and then to two women in uniform getting out of a car in picturesque countryside. A group of children gather around the car, which significantly has 'Save the Children' in English on both sides. As the women hunt about for some chocolate to give 


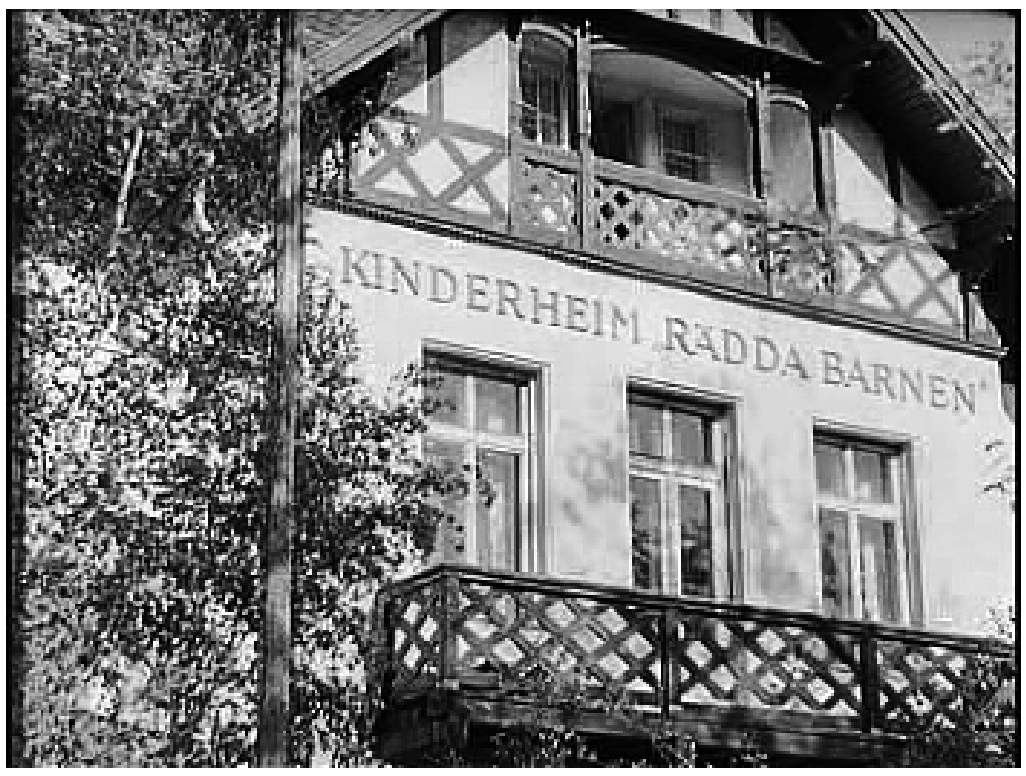

Screenshot from Barnskor ('Children's shoes', 1947, dir. Eduard von Borsody). Courtesy of Sveriges Television AB.

to the children they notice a boy-Peter. He grabs a parcel they had put on the car bonnet and runs off. Like the little girl who ate the entire family's bread ration in Barnen är utan skuld, Peter is caught and confronted. Thanks to the use of high- and low-angle shots-the women at the top of a flight of stairs looking down at Peter, while he looks up at them-the adults are seen literally and visually talking over his head. The confrontation is interrupted by a man, who introduces himself as the children's teacher. He explains that Peter could not have guessed that the chocolate was destined for him and the other children. To make his point, he invites the women into his office, which is dominated by a long shelf full of shoes, and he takes down a worn pair, the tattered soles shown in close-up. He explains that Peter was wearing them when he arrived at the orphanage. The narrative now shifts to Peter and his siblings' past struggle, the second flashback to tell their backstory. When the narrative returns to the orphanage, the teacher explains that Peter ended up in a 'camp', but no further explanation is given; instead, Peter is said to have considered shabby shoes to be his worst problem. 
The women show an interest in the shoes, which encourages the teacher to tell the 'very sad story of Rut'. He is reluctant to tell the actual story of Rut, which he considers too heart-rending, and instead he tells the story of how he revealed what she had gone through. This flashback thus focuses on an incident at the orphanage and is strictly told from the teacher's perspective. The teacher is seen in the sunlit garden and a child is heard screaming 'March! Get in!' He approaches a small girl, who is playing with a little boy, sits down beside them and asks if the cows do not want to go into their barn. Holding a cone in her hand, the girl answers 'that's no barn, that's an oven, and the lady doesn't want to go in. The camera shifts to the boy, who hits another cone with a stick while ordering 'Don't mess around! Get in! Hurry! Hurry!' With a troubled look the teacher leaves the children to themselves and in voice-over explains that 'the children had spent two years in a concentration camp, their parents were gassed'. There is a wipe transition back to the teacher's office. The women look down at his hands, still holding Rut's shoes, and one of them says 'Poor children'.

Their puzzlingly restrained reaction can partly be explained by the nature of the narrative, in which the flashbacks are designed to make the case for the relief work, here accomplished by the RB. However, it also exemplifies what is best defined as phase zero in Holocaust representations. In the late forties and early fifties, the once-explicit representations of the concentration camps, including images of dead bodies, gas chambers, and piles of personal belongings, were replaced by alternative images and narratives, making LaCapra's notion of 'muted trauma' essential. ${ }^{44}$ The restraint of Barnskor, like the adult character's distant reaction to the story within a story, mirrors a general approach in the late forties to the consequences of the Second World War. By invoking this 'muted trauma', the restrained narrative also served the SE's purposes. The assumption was not only that Barnskor's audience would identify with the relief workers' approach, and thus would engage in the problems the children had endured, but they would also be spurred into action and would contribute financially to the SE. The 'muted trauma' so invoked is thus performative.

Prompted by another pair of shoes, which the teacher describes 
'less horrifying than Rut's', the narrative switches to the final flashback: shoes are once again the narrative catalyst, presented as even more 'horrifying' than the stories told. The first shot again shows two feet in worn-out shoes, this time belonging to a grown man returning to an affluent-looking home. When his two daughters finally recognize him they fall into each other's arms. Their reunion is interrupted by a small boy coming into the room, and the father includes him in the family hug. Hastily, the daughters explain that the boy is Hans, their little brother, who was delivered by the stork. Bewildered by their father's reaction, the younger sister realizes 'How could Daddy possibly know that? When Hans arrived, Dad had been gone a long time.' Just as the father lets go of Hans, a woman comes through the front door. When she recognizes her husband, her initial surprise gives way to a look of devastation. Cross-cutting between the spouses' expressions, the father leaves the room. As he walks through the door the camera focuses in on his shoes, and again the teacher's voice links the flashback to the narrative present, concluding Hans's story with the words 'and the door stayed closed.' Like their response to the Rut flashback, the women's reaction to Hans's fate and his little shoes on the shelf is strangely unemotional, their only response being to say 'Poor little Hans' and 'The children are always blameless'-echoing the title of Barnen är utan skuld.

The conclusion of the film is constructed as a happy ending, as the teacher removes a geranium from its pot to illustrate a point about the importance of treating the orphans as plants: 'when they are unwilling to grow, you need to replant them, provide new soil consisting of new thoughts, care, and love'. This is underscored by the sight of the teacher in the sunlit garden, surrounded by welldressed, healthy-looking children, singing in perfect harmony. There are no comments about ethnicity, class, gender, religion, or politics; the orphans at 'Kinderheim Rädda Barnen' are symbolic of any child in need in post-war Europe. 


\section{$\mathrm{RB}$ in Romania}

The paucity of information about the films included in this survey is perhaps most obvious when it comes to Svensk hjälp i Europa-På besök hos Rädda Barnen i Rumänien ('Swedish assistance in Europe-visiting Save the Children in Romania, 1947, dir. anon.). The SFDB entry for the film is fragmentary, while the SMDB has some of the details and a summary of the film, but neither lists a director or production company, and the male voice-over is simply given as 'unknown. ${ }^{45}$

The first sequence of the film has adults sweating in the city of Bucharest, underscored by the voice-over, which says it is as 'hot as a baker's oven'. When the scene shifts to the countryside with parched fields, the voice-over explains that Romania is in the grip of a threeyear drought, and that the starving Romanians are in desperate need of international assistance. This is followed by footage of the domestic and international relief work. The British, who are said to be in need of aid themselves, 'have already generously contributed food parcels formerly intended for the British soldiers during the war'. Ships and trains from Romania's neighbours, Russia and Bulgaria, are arriving with food supplies. There is also a French canteen, and the voice-over remarks that 'the French still remember that the Romanians provided them with grain during the war'.

This initial contextualization is followed by a longer reportage on Swedish relief work in Romania, and the voice-over explains the shift in focus by stating that 'the Swedes are hitherto the only foreigners to have been able to establish and organize long-term assistance in Romania. The simple truth is that in the last year the RB has done miracles'. The voice-over explains that there is Swiss dried milk powder available, and that Switzerland also runs a relief programme in Moldavia, 'yet the Swedish organization has been entrusted to organize the deliveries'. The importance of international cooperation is thus underlined, but while stressing the unique Swedish ability to organize the relief. The statements about trustworthy Sweden being everywhere and reaching everyone are accentuated by the sight of the Swedish flag, primarily on vehicles.

When a small convoy of cars reaches the countryside to deliver supplies, shots of outdoor cooking and children eating from bowls reinforce the voice-over's remarks about a mission accomplished-the 
food they delivered are transformed into a nourishing soup to fill young stomachs. Statements such as 'The soup is always eaten immediately, because of the risk of it ending up in someone else's tummy' serve to stress that the children are surrounded by untrustworthy people, only too ready to take advantage of them. Some of the children are well dressed, and according to the voice-over this is because 'their old rags have already been replaced by Swedish clothes'. After a short sequence to introduce 'the RB centre in southern Moldavia at the Children's Hospital in Galați', the film ends by praising the relief programme. Over shots of well-dressed, healthy-looking schoolchildren in Iași, the voice-over concludes with a brief but glowing evaluation of the completed project with the words 'with that healthy attitude, the RB's project in Romania was accomplished.' This particular film does not include a call for donations, given that the Romanian project was already complete, but it still serves to confirm and promote the work performed by the RB. ${ }^{46}$

\section{Homeless}

The promotion of the RB is also apparent in Hemlösa ('Homeless', 1948 [SFDB], 1951 [SMDB], dir. Karl Zieglmayer \& Karl Sztollar). The SFDB and SMDB both have short descriptions of the plot, but differ widely as to the date, the SFDB claiming that the film was produced in 1948 , while the SMDB has it as $1951 .^{47}$ In fact, the opening credits confirm that it was indeed produced in 1948, by Helios Film in Vienna, and that Kinocentralen in Stockholm did the post-production work.

The co-writers, Elsa Björkman-Goldschmidt and Gunnar Höglund, structured the film as a short melodrama in three acts. ${ }^{48}$ Despite being a work of fiction, the credits stress that 'all settings are authentic', although apart from a road sign pointing towards Budapest, the film lacks place-specific references. The credits are projected over a map of Europe which has Albania, Austria, Bulgaria, Czechoslovakia, Germany, Greece, Hungary, Italy, Poland, Romania, and Yugoslavia highlighted. Consequently, the lack of reference to particular places also means that the story could play out in any of the countries where there were relief projects underway.

A brief introduction spells out the reasons why it was made: 'This 
film wants to show how vile circumstances-distress, hunger, and disorderly conditions-can transform an ordinary boy into one of the many "wild children" currently living in Central Europe.' Arguably, the epithet 'wild children' is as patronizing as Sweden's positioning as rescuing hero is blatant.

The first act takes place in a courtroom, where 14-year-old Robert Timm has been charged with 'serious violence' for shooting Thomas Hober. This scene establishes the melodramatic mode, further underpinned by the musical score and the Swedish dubbing-Hemlösa stands out as the only production in the present survey dubbed into Swedish. Much like the low position of little Peter in the confrontational scene in Barnskor, Robert is placed far below the judge, who initially does not even see him.

The second act then starts with a long flashback, telling the dire story of how Robert ended up in court. It is told from Robert's perspective, so the Swedish is dubbed by a child. First we see Robert's mother sending him off to school, while his beloved dog has to stay at home. Robert's father, who is said to have been killed in the war, is introduced in a close-up of a photograph in their apparently middleclass home. The drama is triggered by bombing, which forces Robert to shelter on his way to school. When the air raid is over he runs home and finds his entire neighborhood in ruins. There is no sign of his mother, but his beloved dog crawls out from the shattered remains of their apartment building. No injured or dead are seen, yet Robert realizes that his mother is beyond hope. He has no one left to turn to there, so accompanied by his loyal dog he sets off on foot to look for his grandmother in Budapest. As Robert is in desperate need of a roof over his head and something to eat, he falls in with a gang of street children in a city just as shattered as the one he left behind-an obvious paraphrase of Charles Dickens's Oliver Twist. ${ }^{49}$ One night Robert is given a pistol with the mission to stand guard while the rest of the gang is asleep. During the night, the slightly older gang member Thomas decides to play a trick on Robert. Thomas knocks on the door, pretending to be the police come to impound Robert's dog, whereupon Robert shoots him.

The third act returns to the narrative present and a resolution. At the trial it is revealed that Thomas is not only alive, he is uninjured. 
As the prosecutor speaks of the importance of 'helping these unfortunate children to a better and happier life', the camera pans across the audience in the courtroom and stops at two women in uniforms decorated with Swedish flags. The next shot shows the very same facade of 'Kinderheim Rädda Barnen' seen in Barnskor, albeit from a slightly different angle. Robert and his dog are shown approaching the orphanage, escorted by a women in RB uniform. Happy children are playing and dancing in the sunlit garden, an obvious parallel to the joyful atmosphere shown in Barnskor.

In the epilogue, representatives from different countries 'providing relief for the distressed people of Europe' are having a round-table meeting. The chairman gives a short speech, dubbed into Swedish, about the relief work performed by countries such as Argentina, Canada, Denmark, the UK, the Netherlands, Norway, Sweden, Switzerland, the US, and 'many more', the countries rhetorically united by their good deeds. This scene is followed by a shot of innumerable young people walking towards the horizon across a sunny meadow, while the chairman's voice concludes: 'The young people are waiting for us, hungry and impatient, and therefore the responsibility is twice as large.' The film comes full circle with another map of Europe, and the closing credits end with an intertitle with 'Slut' (the Swedish word for 'The End') and a musical flourish. The melodramatic mood is thus maintained throughout the film.

\section{Conclusion}

As I have demonstrated here, SE's minutes can be used to chart the development and decline of this short-lived organization. The SE was clearly aware of the promotional, psychological, and emotional impact of film, and this awareness resulted in conscious media strategies for the commissioning and distribution of audiovisual narratives of war and trauma. To enable a more substantial study of the consequences of the organization's media strategies, the films promoted by the SE have been analysed here using a media-specific approach, looking at representations of testimony and trauma.

In general terms, SE's films can be described as educational promotional films, which often explicitly exhort the audience to donate to 
the cause; however, the analysis also shows that the representational modes can range from reportage to melodrama. The same message conveyed in a variety of filmic modes is an efficient way to communicate the essentials to various types of audience. Arguably, the use of different modes indicates a real awareness of the impact and possibilities of the film medium. In relation to the development of Holocaust representations, all the films exemplify LaCapra's notion of 'muted trauma', with a clear avoidance of depicting actual suffering. ${ }^{50}$ Instead, it is the consequences of trauma that are the narrative catalyst, where symbols such as shoes are emblematic of the unmentionable, driving the audience not only to react, but to act-in this case by donating money. This cautious avoidance is also evident in the lack of national specificity - the native and religious origin of the refugees and/or orphans remains unclear. Consequently, these films are of no use in answering the tentative and over-optimistic research question about gradual shifts in the RB's and the SE's approach to children of different national and religious backgrounds in the late 1940 . ${ }^{51}$ When it comes to class, ethnicity, and gender, however, the films are notably inclusive-boys and girls, working, middle, or even upper middle class, it makes no difference; all children of Europe should be saved. That said, the prime focus is the children of Austria and Romania. And neither do the children have a voice of their own-the testimonies of war and trauma are adapted and told from a Swedish relief perspective.

One slightly surprising finding is that the SE is more-or-less invisible in the films. The relief work in focus is first and foremost that done by the RB, the humanitarian organization behind the founding of SE on 9 February 1946. The films similarly are post-war equivalents of the newsreels and short films about the work of the RK screened in the last months of the Second World War, which depict the RK and Sweden alike as holding out a helping hand, primarily in the shape of the rescue action with the White Buses. This kind of marketing had proved valuable in more than one way. The founding of SE hence would have seemed like an excellent idea, not only for Europe's children in need, but for the post-war marketing purposes of the RB and the goodwill of Sweden. ${ }^{52}$ 


\section{Notes}

1 Barnen är utan skuld-Svenska hjälpverksamheten $i$ Wien ('The children are blameless-The Swedish relief programme in Vienna, 1946, dir. Eduard von Borsody). All translations are mine unless otherwise stated.

2 Joshua Hirsch, Afterimage: Film, trauma, and the Holocaust (Philadelphia: Temple University Press, 2004), 18-19; Dominick LaCapra, 'Lanzmann's "Shoah": Here there is no why', Critical Inquiry, 23/2 (1997), 231-69.

3 Cecile Felicia Stokholm Banke, 'Remembering Europe's Heart of Darkness: Legacies of the Holocaust in post-war European societies', in Małgorzata Pakier \& Bo Stråth (eds.), A European memory? Contested memories and politics of remembrance (New York: Berghahn, 2010), 163-74.

4 Ibid. 170.

5 Ibid. 170 .

6 Ibid. 173 .

7 Ibid. 171.

8 Ibid. 174 .

9 LaCapra, 1997, 250.

10 Raul Hilberg, 'Developments in the historiography of the Holocaust', in Asher Cohen et al. (eds.), Comprehending the Holocaust: Historical and literary research (Frankfurt am Main: Peter Lang, 1988), 21.

11 Raul Hilberg, The destruction of the Euoropean jews (Chicago: Quandrangle, 1961). For the problems associated with its publication, see Raul Hilberg, The politics of memory: The journey of a Holocaust historian (Chicago: Ivan R. Dee, 1996), 105-19.

12 Dori Laub, 'Truth and testimony: The process and the struggle', in Cathy Caruth (ed.), Trauma: Explorations in memory (Baltimore: Johns Hopkins University Press, 1995), 65.

13 Daniel Levy \& Natan Sznaider, Human rights and memory (University Park, PA: Pennsylvania State University Press, 2010), 48-49.

14 See Sturfelt's chapter in this volume.

15 See, for example, Lena Einhorn, Handelsresande i liv: Om vilja och vankelmod $i$ krigets skugga (Stockholm: Prisma, 1999); Jean-Claude Favez, The Red Cross and the Holocaust (Cambridge: CUP, 1999); Ingrid Lomfors, Blind fläck: Minne och glömska kring svenska Röda Korsets hjälpinsats i Nazityskland 1945 (Stockholm: Atlantis, 2005); Sune Persson, 'Vi åker till Sverige’: De vita bussarna 1945 (Rimbo: Fischer, 2002); Åke Svenson, De vita bussarna (Stockholm: Bonnier, 1945); http://www.redcross.se/, s.v. 'Vita bussarna' (accessed 1 Nov. 2015).

16 Ann Nehlin, Exporting visions and saving children: The Swedish Save the Children Fund (diss.; Linköping: Department of Child Studies, 2009), 198.

17 http://www.redcross.int/, s.v. 'history' (accessed 1 Nov. 2015).

18 http://www.redcross.se/, s.v. 'historik' (accessed 1 Nov. 2015).

19 http://www.redcross.se/, s.v. 'passagerarlistor', 'Vita Bussarna' (accessed 1 Nov. 2015).

20 https://www.savethechildren.net/, s.v. 'history' (accessed 1 Nov. 2015). 
21 https://www.raddabarnen.se/, s.v. 'historik' (accessed 1 Nov. 2015).

22 Riksarkivet, Svenska Europahjälpen (SE), Protokoll 1946-1951, Vol. 1, 9 Feb. 1946.

23 Ibid. 9 Feb. 1946.

24 Ibid. 15 Feb. 1946.

25 Ibid.

26 Ibid.

27 Ibid. 21 Dec. 1951.

28 Ibid. 15 Feb. 1946.

29 Ibid. 25 Apr. 1946.

30 Ibid. 4 Sept. 1947.

31 Ibid. 28 Nov. 1947.

32 Ibid. 3 Mar. 1949.

33 Ibid. 21 Dec. 1951.

34 http://www.sfi.se/sv/svensk-filmdatabas/, s.v. '40 år med Kungen' (accessed 1 Nov. 2015); https://smdb.kb.se/, s.v. '40 år med Kungen' (accessed 1 Nov. 2015).

35 Riksarkivet, SE, Protokoll 1946-1951, Vol. 1, 1 Dec. 1948.

36 http://www.sfi.se/sv/svensk-filmdatabas/, s.v. 'Barnskor,' 'Hemlösa' (accessed 1 Nov. 2015); https://smdb.kb.se/, s.v. 'Barnskor,' 'Barnen är utan skuld,' 'Hemlösa', 'Med Rädda Barnen i Rumänien' (accessed 1 Nov. 2015).

37 All copies of the films included in the survey were provided by SMDB.

38 Eduard von Borsody (1898-1970) was an Austrian cameraman, film editor, screenwriter, and director; for Willi Forst see, for example, Robert von Dassanowsky, Austrian cinema: A history (Jefferson: McFarland, 2005); however, Dassanowsky does not mention the fact that Borsody directed Barnen är utan skuld in 1946 and Barnskor in 1947.

39 https://smdb.kb.se/, s.v. 'Barnen är utan skuld' (accessed 1 Nov. 2015).

40 Willi Forst (1903-1980) was an Austrian actor, singer, scriptwriter, director, and producer, and much appreciated by German-speaking audiences. As a director he is still considered one of the most significant filmmakers of the Viennese period musical melodramas and comedies of the 1930s, known as Wiener Filme. In 1936, Forst founded his own film production company, Willi Forst-Film, in Vienna, followed by a branch in Berlin (Dassanowsky, 2005).

41 After a government decision on 10 March 1939, English replaced German as the first foreign language studied in Swedish schools. The reform was gradually introduced and it was not until 26 Aug. 1946 that all Swedish schools had made the curriculum changes.

42 Levy and Sznaider, 2010, 49 recognize the paradoxical impact of the emotive dimensions that guided reactions to the catastrophes of the Second World War and to the Holocaust in particular: 'Paradoxically, the Holocaust functioned simultaneously as the source for a critique of Western universalism and the foundation for a cosmopolitan desire to propagate human rights universally' http://www.sfi.se/sv/svensk-filmdatabas/, s.v. 'Barnskor' (accessed 1 Nov. 2015); https://smdb.kb.se/, s.v. 'Barnskor' (accessed 1 Nov. 2015).

44 LaCapra, 1997, 250. 
45 http://www.sfi.se/sv/svensk-filmdatabas/, s.v. 'Svensk hjälp i Europa-På besök hos Rädda Barnen i Rumänien' (accessed 1 Nov. 2015); https://smdb.kb.se/, s.v. 'Svensk hjälp i Europa-På besök hos Rädda Barnen i Rumänien' (accessed 1 Nov. 2015).

46 The RB project in Romania and the impact of the Securitate (the secret police agency in Communist Romania, 1948-1991), is scrutinized by Vadim Guzun (ed.), Rädda Barnen și Securitatea: Documente româno-suedeze 1946-1949 (Clju-Napoca: Argonaut, 2015); however, Guzun does not include any kind of film material.

47 http://www.sfi.se/sv/svensk-filmdatabas/, s.v. 'Hemlösa' (accessed 1 Nov. 2015); https://smdb.kb.se/, s.v. 'Hemlösa' (accessed 1 Nov. 2015).

48 Elsa Björkman-Goldschmidt (1888-1982) was a key figure in RB, not least because of her involvement in relief work in Vienna after the two World Wars; see Elsa Björkman-Goldschmidt, 'Så var det i Wien', in Vera Forsberg, Att rädda barn: En krönika om Rädda Barnen med anledning av dess femtioåriga tillvaro (Stockholm: Rädda Barnens Riksförbund, 1969).

49 Charles Dickens, Oliver Twist: Or the parish boy's progress (London: Richard Bentley, 1838).

50 Hirsch, 2004, 18-19; LaCapra, 1997, 250.

51 Nehlin, 2009, 198.

52 Without discussing film, Nehlin, 2009, 198 arrives at similar conclusions in her analysis of the RB.

\section{References Archival sources}

Riksarkivet, Stockholm (RA), Svenska Europahjälpen, Protokoll 1946-1951, vol. 1.

\section{Electronic sources}

Rädda Barnen, http://www.raddabarnen.se/, s.v. 'historik' (accessed 1 Nov. 2015). Red Cross International, http://www.redcross.int/, s.v. 'history' (accessed 1 Nov. 2015). Röda Korset, http://www.redcross.se/, s.v. 'historik', 'passagerarlistor,' 'Vita Bussarna' (accessed 1 Nov. 2015).

Save the Children International, https://www.savethechildren.net/, s.v. 'history' (accessed 1 Nov. 2015).

Svensk Filmdatabas, http://www.sfi.se/sv/svensk-filmdatabas/, s.v. 40 år med Kungen, Barnen är utan skuld-Svenska hjälpverksamheten $i$ Wien, Barnskor, Hemlösa, Svensk hjälp i Europa-Med Rädda Barnen i Rumänien (accessed 1 Nov. 2015). Svensk mediedatabas, https://smdb.kb.se/, s.v. 40 år med Kungen, Barnen är utan skuld, Barnen är utan skuld-Svenska hjälpverksamheten $i$ Wien, Barnskor, Svensk hjälp i Europa-Med Rädda Barnen i Rumänien (accessed 1 Nov. 2015). 


\section{Filmography}

40 år med Kungen ('40 years with the King') (1947, dir. Gösta Werner).

Barnen är utan skuld_Svenska hjälpverksamheten $i$ Wien ('The children are blameless-The Swedish relief programme in Vienna') (1946, dir. Eduard von Borsody). Barnskor ('Children's shoes') (1947, dir. Eduard von Borsody).

Hemlösa ('Homeless') (1948 [Svensk Filmdatabas], 1951 [Svensk mediedatabas], dir. Karl Zieglmayer \& Karl Sztollar).

Shoah (1985, dir. Claude Lanzmann).

Svensk hjälp i Europa-På besök hos Rädda Barnen i Rumänien ('Swedish assistance in Europe-Visting Save the Children in Romania') (1947, dir. anon.)

\section{Secondary sources}

Aftonbladet, 7 May 1945.

Björkman-Goldschmidt, Elsa, 'Så var det i Wien', in Vera Forsberg, Att rädda barn: En krönika om Rädda Barnen med anledning av dess femtioåriga tillvaro (Stockholm: Rädda Barnens Riksförbund, 1969).

CTO, 'SAGA: 40 år med Kungen', Stockholms-Tidningen, 9 Dec. 1947.

Dassanowsky, Robert von, Austrian cinema: A history (Jefferson: McFarland, 2005).

Dickens, Charles, Oliver Twist: Or the parish boy's progress (London: Richard Bentley, 1838).

Einhorn, Lena, Handelsresande i liv: Om vilja och vankelmod i krigets skugga (Stockholm: Prisma, 1999).

Favez, Jean-Claude, The Red Cross and the Holocaust (Cambridge: CUP, 1999).

Göteborgs-Posten, 8 May 1945.

Guzun, Vadim (ed.), Rädda Barnen și Securitatea: Documente româno-suedeze 1946-1949 (Clju-Napoca: Argonaut, 2015).

Hilberg, Raul, The destruction of the European jews (Chicago: Quandrangle Books, 1961).

- The politics of memory: The journey of a Holocaust historian (Chicago: Ivan R. Dee, 1996).

Hirsch, Joshua, Afterimage: Film, trauma, and the Holocaust (Philadelphia: Temple University Press, 2004).

J.-v., 'Kunglig filmkavalkad på Saga', Svenska Dagbladet, 9 Dec. 1947.

LaCapra, Dominick, 'Lanzmann's "Shoah": Here there is no why', Critical Inquiry, 23/2 (1997) 231-69.

Laub, Dori, 'Truth and testimony: The process and the struggle', in Cathy Caruth (ed.), Trauma: Explorations in memory (Baltimore: Johns Hopkins University Press, 1995).

Levy, Daniel \& Natan Sznaider, Human rights and memory (University Park, Penn.: Pennsylvania State University Press, 2010).

Lomfors, Ingrid, Blind fläck: Minne och glömska kring svenska Röda Korsets hjälpinsats i Nazityskland 1945 (Stockholm: Atlantis, 2005).

Nehlin, Ann, Exporting visions and saving children: The Swedish Save the Children 
Fund. (diss.; Linköping: Department of Child Studies, Linköping University, 2009). Odd, '40 år med kungen', Dagens Nyheter, 9 Dec. 1947.

Persson, Sune, 'Vi åker till Sverige': De vita bussarna 1945 (Rimbo: Fischer, 2002). Stokholm Banke, Cecile Felicia, 'Remembering Europe's Heart of Darkness: Legacies of the Holocaust in Post-War European Societies', in Małgorzata Pakier \& Bo Stråth (eds.), A European memory? Contested memories and politics of remembrance (New York: Berghan Books, 2010), 163-74.

Svenson, Åke, De vita bussarna (Stockholm: Bonnier, 1945).

Sydsvenska Dagbladet Snällposten, 6 May 1945. 